\title{
THE IMPORTANCE OF LOCAL GOVERNMENT IN POLAND-GENERAL ISSUES
}

\begin{abstract}
Proper management of the public interest in Poland is realized on the basis of territorial divisions of the country. Territorial division is a kind of fragmentation of the country in order to establish the relevant authorities of the state or non-state entities which perform the tasks of a public nature. The divisions are created in order to introduce law and order activity of bodies and entities performing the tasks of the state. One of the divisions is essential territorial division of the country also known as the basic one, or general, whose units are: commune, district and province. Local government because of rationing and allocation of powers has a specific location, which is to carry out tasks resulting from the coming needs and problems of the local community, as well as regional and. The division of competence is aimed at not only meeting the needs necessary for the proper functioning of the local government unit and its residents, but also fully indeed an important role in the economic development of the unit, and consequently the whole country. The purpose of the proper implementation of tasks and their full effectiveness, it is important that local governments operate effectively, and above all transparent to everyone in the local community. Relations between the administration and the citizen should be based on trust. Building positive relationships is essential to the implementation of initiatives in a particular territory. The article presents the essence of local government and takes its general characteristics.
\end{abstract}

Keywords: administration, territorial division, authority, local government.

The efficiency of the functioning of the state as a social organization is subject to the proper management of public interest. Therefore, a division of the administrative structure into several categories in which, one of them is the local government. Local government has a specific location, which stems from its proximity to the problems of local and regional communities. Due to a very good identification of the needs and requirements of the local community by the local government, the tasks assigned to it is indeed important for the economic development of the unit and consequently the whole country. For these tasks to be performed in an efficient manner, it is important that the local government act in a timely and understandable manner to everyone in the local community. Local government is divided into provinces, districts and municipalities. The basic organizational unit of local government is the municipality.

${ }^{1}$ Dr Oktawia Jurgilewicz, Katedra Prawa i Administracji, Wydział Zarządzania, Politechnika Rzeszowska, Al. Powstańców Warszaw 8, 35-959 Rzeszów, tel. 17865 1721, e-mail: niemieco@prz.edu.pl 
The basic definition of local self-government says that local government is a community of residents involved in the exercise of public authority residing in the territory ${ }^{2}$.

Through the concept of self-government it is also widely understood the law established for independent and independent conduct of their affairs ${ }^{3}$.

The literature presented extends an idea of some of the features and functions specific to this type of club. The literature emphasizes that it is one part of the public administration, which is characterized by a kind of isolation and therefore the lack of connections with other units of local government as a result of lack of hierarchy, dependencies and some sovereignty against the entire state ${ }^{4}$

According to W. Kosiedowski, local government authorities also have the function of administration in addition to management function ${ }^{5}$.

The local gov't have legal personality: civil law, which is manifested by the possibility of incurring liabilities and having your own property, whose purpose and use are decided independently; as well as public law, ie. can benefit from the resources of governmental authority, or establish a legal relationship with the state authorities. Independently manage municipal property, which is their own, have the ability to run your own business, but only as part of the public tasks ${ }^{6}$.

The activities of local governments cannot in any way violate the principles of the free market and competition. Interference in the private sector is limited to taking care of a balanced and dynamic development of the sector, to support existing businesses and to take measures to create favorable conditions for economic development to attract potential foreign and domestic investors.

The existence of local government can be considered in two aspects:

- legal, relating to all legal acts that regulate the necessity of selfgovernment,

- political, concerning the interconnections between the local administration and the government ${ }^{7}$.

The most important source of Polish law, the Polish Constitution of 2 April $1997^{8}$. Legislator has concluded that contains the essence of the legal basis for the existence of local government. In Art. 15 paragraph. 2 The Constitution contains the principle of decentralization of public administration tasks added: "The territorial system of the Republic of Polish provides decentralization of public power" and Art. 16 paragraph. 2 shows the principle of subsidiary, "local government participates in the exercise of public power. He is entitled to a substantial part of public self-performed tasks on its own behalf and on his own responsibility. "

${ }^{2}$ B. Zawadzka, Principle of local participation in the exercise of power, [in:] Basic Principles of the Polish Constitution, Warsaw 1998, p. 203.

${ }^{3}$ M. Chmaj, Administrative Law. General part, Warsaw, 2003, p. 212.

${ }^{4}$ A.K Piasecki, Local government and local communities, Warsaw 2009, p. 30.

${ }^{5}$ W. Kosiedowski, regional and local economy, ed. Z. Strzelecki, Warsaw 2008, p. 229.

${ }^{6}$ Ibid, p. 229.

${ }^{7}$ Z. Leoński, Local government in Poland, ed. S. Wykrętowicza, Poznań 2001, p. 104.

${ }^{8}$ Dz. Laws of 1997 , no. 78 , pos. 483, as amended zm., Hereinafter referred to as the Constitution of the Republic of Poland. 
Another aspect of the law, talking about the essence of self-government by the Constitution is to give RP a legal personality to local government units, which gives them the right to be a party in civil law relations ${ }^{9}$. To be fully able to use their capacity to perform legally, local government units has also been attributed to financial independence ${ }^{10}$. This means that the local authorities completely \& independently manage their budget, and therefore decide which public tasks, and what measures will be used on their projects during the period.

Another aspect of the law on local self-government is the requirement of holding elections of local authorities in a democratic manner ${ }^{11}$. Doing so triggers a sense of responsibility for the residents of a given community, taking care of a good deal, and induces a feeling of belonging to the local government units.

The legal basis for the presence of local government in the international arena governed by two acts. The first is the World Declaration on Local Self-Government, which was enacted on September 22-26, 1985. in Rio de Janeiro on the 27th World Congress of the International Association of local authorities. It provides that "the local government is the right and duty of local authorities to local regulation and management of public affairs for the good of the community" (Art. 2. 1) and that "all the rules and powers of local authorities must be enshrined in the constitution or established by legislation "(art. 1 and 3.3) $)^{12}$.

The second piece of legislation relating to local government is passed 15 October 1985 in Strasbourg, the European Charter of Local Self local ${ }^{13}$ whereby .:

- basis for the existence of local government in the country should be adequately regulated by law in the internal laws and regulations and, where possible, in the Constitution (Article 2),

- local government denotes the right and ability of local communities to shape and regulated for - under the law - part of public affairs under their own responsibility and in the interests of their citizens (Article 3$)^{14}$.

Both of the above-mentioned legislation argue that local government is a basic constitutionally-legal institution of the modern state, which is the closest to the society and thus meet its basic needs.

The independence of local government units and therefore the lack of any hierarchical subordination to government authorities makes it in some situations may lead to disputes with the central government ${ }^{15}$. This phenomenon is called Z. Leoński "fighting back with the state of society," which may occur when the central government and local governments belong to different political forces are characterized by different

${ }^{9}$ Art. 165 , paragraph. 1 of the Constitution.

${ }^{10}$ Art. 167, paragraph. 1 of the Constitution.

${ }^{11}$ Art. 169 of the Constitution.

${ }^{12}$ B. Dolnicki, Polish local government in a European context, the university newspaper. Monthly Universities of Silesia in Katowice, 2002, No. 2 (102), p. 28.

${ }^{13}$ Dz. Laws of 1994, no. 124, item. 607, as amended. d., until 2006. functioned under the European Charter of Local Self-Government.

${ }^{14}$ Ofiarski Z., M. Mokrzyca, B. Rutkowski, Local Government Reform Volume II Legal and financial issues, Zielona Góra 1999, p.17.

${ }^{15}$ Z. Leoński, Local Government in Poland ..., p. 9. 
programs of action. This situation is most positive for society and the economy, as there is mutual supervision and control between local and central government and between the various political groups.

In some cases, local governments can also be used as part of a political struggle. Competition concerns a local authority, which can also contribute to later success in the struggle for the central authorities ${ }^{16}$. Exists between the various political fractions. Is called positive with respect to the policies pursued by governments thus introducing competition phenomenon.

Local government can also be a good school of management. Forming relationships with the public and the public authority requires appropriate competence and character traits. It is important that these relationships are based on trust. This is very important in the implementation of new initiatives in the territory. Society must have felt that governments act in the best interests of their, and governmental administration must be sure that the tasks that have been its delegated towards decentralization will be carried out in a proper manner. Autonomy allows you to take some kind of experience and habits enabling win people over. It is therefore important that the process was led by people with appropriate competence and confidence with the public, which gives them their vote in free elections ${ }^{17}$.

It should be emphasized that the local government carries out its functions on the principle of decentralization and autonomy. It is not subordinated to the state administration bodies, not appointed by it and cannot be canceled by it. It should be remembered that the independence in the tasks of independence does not mean unlimited. Local government associations, performing tasks of the state, should remain under his supervision. Of local self-reliance cannot be understood in its full independence from the state, but in terms of a precise definition of the cases, when the state in the sphere of local government may intervene. The scope of local government autonomy is thus determined by the Supervision of its activities ${ }^{18}$.

Local government is appointed to carry out the tasks of the state, and more specifically the performance of state administration (the subject of local government). The fact that territorial performs state administration no longer raises any doubts. Tasks within the scope of this administration are taken by the government and the local government. The activities of the government and the local government is in its material content and bears jednorodzajowa state character.

As a result of local government autonomy should not be sought in the fact that its total independence from the state, but the precise definition of cases where the state can intervene in the sphere of local government (supervision). In addition to these cases, the state cannot interfere in the sphere of its activity ${ }^{19}$.

Supervision is a guarantor of the independence of self-government, but about the field of local government to decide the rules on supervision. Such a view is dominant in the literature, in which the government oversight of government rises to the level of the basic indications of the essence ${ }^{20}$.

\footnotetext{
${ }^{16}$ Ibid p. 34.

${ }^{17}$ S. Wykrętowicz, Local government in Poland, Poznan 2004, p. 117.

${ }^{18}$ M. Chmaj, Administrative Law ..., p. 213.

${ }^{19}$ Z. Niewiadomski, Administrative Law, Warsaw 2013, p. 144.

${ }^{20}$ Ibid, p. 144.
} 
Local government in Poland was divided into three levels: the commune, district and province.

In view of regulation of art. 16 paragraph. 2 of the Constitution, the local government is responsible for the realization of a substantial part of the public tasks. Publicity and define two facts. Firstly, these tasks are governed by the relevant laws and so local governments cannot undertake tasks which are not reserved for them under the relevant legislation. The second fact is that the government in fulfilling its tasks running the public interest and is therefore part of the public authority.

Types of public tasks carried out by local government units are defined by relevant laws: on local government, county and local government of the region.

According to the definition set out on an electronic platform administrative services (EPUAP) is a public task "task that is required to implement in a public institution. ${ }^{21 "}$

The Constitution divides public tasks own tasks and commissioned. "Public duties aimed at satisfying the needs of the local community are made by the local government as their direct responsibility" (art. 166, paragraph. 1) and "if this is due to the legitimate needs of the state, a statute may instruct units of local government to perform other public duties. The Act specifies the mode of transmission and how to perform tasks assigned ${ }^{22 "}$.

Another document divides the public tasks own tasks and ordered the Local Government Act of 8 March $1990^{23}$.

The task of their own self-government is a public task assigned by the law of the selfgoverning unit, for the execution of which shall be fully liable. Local government units in accordance with relevant laws perform tasks on its own behalf and on his own responsibility. It comes down to the fact that the people contrary to popular belief they meet their own needs. They do this through democratic elections, in which the authorities are free to choose and then entrust them to meet the tasks meet the needs of the community to which they belong.

However, there are some restrictions on the activities of local governments. The Polish constitution does not allow full freedom of action in meeting the needs of society.

Parliament, through the introduction of appropriate legislation sets out the principles of local organization, its structure and division of tasks between the different local government units. This is due to applied principle of subsidiary in mind, some of its tasks should be carried out by the authorities who are closest to the citizen.

The Province carries out the tasks specified in the regional self-government, mainly in the area of: public education, including higher education, health promotion and protection, culture and the protection of its assets, social, family policy, modernization of rural areas, zoning, environmental, economic water, public transport and public roads, physical culture and tourism, protection of consumer rights, defense, public safety, prevention of unemployment and the acquisition of the local labor market ${ }^{24}$. Additionally the region can

\footnotetext{
${ }^{21} \mathrm{http}: / /$ www.e-puap.mswia.gov.pl.

${ }^{22}$ Art. 166, paragraph. 1 and 2 of the Constitution.

23 Art. 8.9 of the Act of March 8, 1990. Local Government Acts. Laws of 2013. Pos. 594, consolidated text.

${ }^{24}$ Art. 14 of the Act of 5 June 1998. of the Regional Government Journal of Laws of 2013. pos. 596, consolidated text.
} 
perform tasks related to the organization of the preparation and conduct of the general elections and referendums imposed on them by law.

The Management Board of the province can perform the tasks of government belonging to the scope of the province. The transfer of these tasks is usually followed by appropriate legislation.

The District performs the duties of a supra-public, as defined in the Act, particularly in the following areas: public education, health promotion and protection, family policy, support for the disabled, transport and public roads, culture and protection of cultural, physical culture and tourism, geodesy, cartography and cadastre, real estate management, administration, architectural-building, water management, environmental protection and nature conservation, agriculture, forestry and inland fisheries, public order and public safety, flood protection, fire protection and prevention of other extraordinary threats to the life and health of people and the environment, combating unemployment and activation of the local labor market, consumer protection, maintenance of district facilities and equipment and facilities of public administration, defense, promote the county, cooperation with NGOs. District cancannotnot perform the tasks within the scope of activities of the municipality, in exceptional circumstances, a justified request of the municipality may transfer its realizations tasks covered by the county ${ }^{25}$.

District by law or agreement shall perform the duties belonging to the business of government. The implementation of these tasks is funded through a grant from the government, which has the competence and authority to control and supervise the correctness of the delegated tasks ${ }^{26}$.

The tasks of the county must also perform the tasks of district services, inspections and guards that do not classify themselves to their own tasks or commissioned. Units meeting the tasks are their managers, who do not belong to the authorities of the county as well as not under their sovereignty missions ${ }^{27}$.

The Municipality performs tasks related to: spatial management, real estate, environmental and nature conservation and water management, municipal roads, streets, bridges, squares and traffic organization, water supply and water supply, sanitation, disposal and waste water treatment, maintaining cleanliness and order and sanitation facilities, landfills and disposal of municipal waste, supply of electricity, heat and gas; activities: telecommunications, local public transport, health, social welfare, including the centers and welfare institutions, municipal housing, public education, culture, including municipal libraries and other cultural institutions and the protection of monuments and care of monuments, physical culture and tourism, including recreational and sports facilities, markets and exhibition halls, municipal and greenery of trees, cemeteries, municipal, public order and the safety of citizens and fire and flood, including equipment and maintenance of municipal flood storage, maintenance of facilities and equipment municipal utilities public and administrative facilities, family-friendly policies, including the provision of care to pregnant women social, medical and legal assistance, promotion and dissemination of the idea of self-government, including the creation of conditions for operation of auxiliary units develop and implement programs to stimulate active

${ }^{25}$ Art. 4 of the Act of 5 June 1998. District Government (Journal of Laws of 2013. Pos. 595, consolidated text.

${ }^{26} \mathrm{~J}$. Wyporska, Local government in Poland, Warsaw 2004, p. 62.

${ }^{27}$ B. Dolnicki, Local government, Warsaw 2009, p. 283. 
citizenship; promotion of the municipality, co-operation and activities of nongovernmental organizations, cooperation with local and regional communities of other countries $^{28}$.

An important point to be emphasized is that the law defining the tasks of their own municipalities are obligatory. The important thing is that in case of transfer of the municipality of the new tasks of their own, it is necessary to provide adequate funding for their projects. Usually manifests itself by increasing the income of the municipality, or in additional subsidies.

The municipality also performs the tasks of government. By imposed laws organizes, prepares, conduct voting and general elections ${ }^{29}$. Other tasks of the government administration implements under agreements concluded with these authorities. For these tasks municipality receives adequate funding and whose mode of transmission rules specified in the status ${ }^{30}$.

Local government issue is extensively described in the literature and widely discussed on the basis of legal and political sciences. The concept of self-learning has become an administrative law is one of the most important concepts. This is due to both the rich tradition of the Polish lands and also always have been important in the construction of Polish democracy.

It is also pointed that, the local government does not arise through the free act of the founding members therefore cannot be resolved or an act of the will of the members. Justi-regardless of being self-will of the legislature is that belonging to the local community, therefore, arises by operation of law, in connection with residence in a given area, and lasts as long as a person usually resides there. Living is the only requirement for membership in the local government. Member is therefore independent of its activity in its activities. A person cannot refuse membership to the association of local government authorities while the authorities cannot therefore excluded. Union affiliation, apparently bearing the characteristics of forced (arises by operation of law, regardless of the will of the people), in fact this is not so. A resident in the area can be quite passive. Passivity and are not precluded from compound ${ }^{31}$.

The functioning of local government is based on the three-divisions, where we distinguish municipalities, counties and provinces. The commune is the smallest unit, but also the best equipped with the ability to manage their territory.

\section{LITERATURE:}

1. Chmaj M., Administrative Law. General part, Warsaw, 2003, p. 212.

2. Dolnicki B., Polish local government in a European context, the university newspaper. Monthly Universities of Silesia in Katowice, 2002, No. 2 (102), p. 28.

3. Góralczyk W., Principle of competence in administrative law, Warsaw 1986, p. 105.

4. Kosiedowski W., Regional and local economy, ed. Z. Strzelecki, Warsaw 2008, p. 229.

5. Leoński Z., Local government in Poland, ed. S. Wykrętowicza, Poznań 2001, p. 104.

6. Ofiarski Z., M. Mokrzyca, B. Rutkowski, Local Government Reform Volume II Legal and financial issues, Zielona Góra 1999, p.17.

\footnotetext{
${ }^{28}$ Art. 7 of the Local Government Act.

${ }^{29}$ J. Wyporska, Local Government ..., s. 59.

${ }^{30}$ Art. 8 of the Local Govemment Act.

${ }^{31}$ W. Góralczyk, Principle of competence in administrative law, Warsaw 1986, p. 105.
} 
7. Piasecki A.K., Local government and local communities, Warsaw 2009, p. 30.

8. Zawadzka B, Principle of local participation in the exercise of power, [in:] Basic Principles of the Polish Constitution, Warsaw 1998, p. 203.

\section{ISTOTA SAMORZĄDU TERYTORIALNEGO W POLSCE- ZAGADNIENIA OGÓLNE}

Prawidłowe zarządzanie interesem publicznym w Polsce realizowane jest na podstawie podziałów terytorialnych kraju. Podział terytorialny stanowi swoiste rozczłonkowanie kraju celem ustanowienia odpowiednich organów państwa lub też jednostek niepaństwowych, które wykonują jego zadania o charakterze publicznym. Podziały tworzone są celem wprowadzenia ładu i porządku działalności organów i podmiotów realizujących zadania państwa. Jednym $\mathrm{z}$ podziałów jest zasadniczy podział terytorialny państwa zwany też podziałem podstawowym lub też ogólnym, którego jednostkami są: gmina, powiat i województwo. Samorząd terytorialny z uwagi na reglamentację oraz podział kompetencji posiada specyficzne usytuowanie, które ma realizować zadania wynikające z najbliższych potrzeb i problemów społeczności lokalnej, jak też i regionalnej. Podział kompetencji ma na celu nie tylko realizację potrzeb niezbędnych dla prawidłowego funkcjonowania jednostki samorządu lokalnego i jej mieszkańców, ale też pełni istotnie ważną rolę dla rozwoju gospodarczego danej jednostki, a w konsekwencji i całego kraju. Celem prawidłowej realizacji zadań $i$ ich pełnej efektywności ważne jest, aby samorząd terytorialny funkcjonował sprawnie, a przede wszystkim przejrzyście dla każdego mieszkańca danej społeczności lokalnej. Relacje pomiędzy organem administracji a obywatelem winny być oparte na zaufaniu. Budowanie pozytywnych relacji ma istotne znaczenie przy wdrażaniu inicjatyw na poszczególnym terytorium. Społeczeństwo winno mieć poczucie, iż samorządy działają w jego najlepszym szeroko pojmowanym interesie (w zależności od przyznanych kompetencji). Samorząd realizuje swoje zadania na zasadzie decentralizacji jak też działa samodzielnie. Artykuł prezentuje istotę samorządu terytorialnego i podejmuje jego ogólną charakterystykę.

Słowa kluczowe: administracja, podział terytorialny, organ administracji, samorząd terytorialny.

DOI:10.7862/rz.2015.hss.4

Przesłano do redakcji: luty 2015

Przyjęto do druku: czerwiec 2015 
